IZA DP No. 6358

The Short-Term Effectiveness of a Remedial Mathematics Course: Evidence from a UK University

Giorgio Di Pietro

February 2012 


\title{
The Short-Term Effectiveness of a Remedial Mathematics Course: Evidence from a UK University
}

\author{
Giorgio Di Pietro \\ Westminster Business School \\ and IZA
}
Discussion Paper No. 6358
February 2012

\author{
IZA \\ P.O. Box 7240 \\ 53072 Bonn \\ Germany \\ Phone: +49-228-3894-0 \\ Fax: +49-228-3894-180 \\ E-mail: iza@iza.org
}

\begin{abstract}
Any opinions expressed here are those of the author(s) and not those of IZA. Research published in this series may include views on policy, but the institute itself takes no institutional policy positions.

The Institute for the Study of Labor (IZA) in Bonn is a local and virtual international research center and a place of communication between science, politics and business. IZA is an independent nonprofit organization supported by Deutsche Post Foundation. The center is associated with the University of Bonn and offers a stimulating research environment through its international network, workshops and conferences, data service, project support, research visits and doctoral program. IZA engages in (i) original and internationally competitive research in all fields of labor economics, (ii) development of policy concepts, and (iii) dissemination of research results and concepts to the interested public.
\end{abstract}

IZA Discussion Papers often represent preliminary work and are circulated to encourage discussion. Citation of such a paper should account for its provisional character. A revised version may be available directly from the author. 
IZA Discussion Paper No. 6358

February 2012

\section{ABSTRACT}

\section{The Short-Term Effectiveness of a Remedial Mathematics Course: Evidence from a UK University*}

Whilst in the US there is a growing debate about the effectiveness of remedial university courses, this issue is less questioned in the UK. Using a regression discontinuity approach and data from a large School of a post-1992 UK university, we estimate the effect of remediation on student outcomes. We find no evidence that attending a math remedial program improves student performance in the first year. This finding is consistent and complements that of a recent study by Lagerlöf and Seltzer (2009), which is based on data from a pre-1992 UK university. Taken together, these results may call for a review of the remediation policy offered at university level in the UK.

JEL Classification: A22, 120

Keywords: regression discontinuity design, remedial mathematics, student performance

Corresponding author:

Giorgio Di Pietro

University of Westminster

Westminster Business School

Department of Economics and Quantitative Methods

35 Marylebone Road

NW1 5LS London

United Kingdom

E-mail: G.D.I.Pietro@westminster.ac.uk

${ }^{*}$ Financial support received by the Economics Network of the Higher Education Academy is gratefully acknowledged. 


\section{INTRODUCTION}

Higher education has undergone significant expansion in recent decades in several OECD countries. Expansion has been particularly dramatic in the UK where the number of students enrolled at higher education institutions (HEIs) increased from about 400,000 in the early 1960 s to just less than $2,400,000$ in $2008^{1}$. Several commentators see this massive increase in enrolment as a key step for providing educational opportunity for people from less-advantaged backgrounds. Additionally, graduates are also considered to be a crucial component of a knowledge-based economy.

However, one of the concerns related to this impressive growth is that a large number of students accepted into higher education may not be fully prepared for this level of study. They may not have adequate academic skills in crucial areas such as mathematics, reading and writing. In an attempt to address this problem, colleges and universities have set up remedial courses ${ }^{2}$. These courses are often specifically designed for first-year students and their aim is to help to bridge any gaps between students' knowledge and the requirements for their degree courses. However, despite the need, remedial university programs are a controversial topic. Critics argue that these programs should not exist given that unprepared students should not have been allowed to have access to university education. Providing remedial education at higher education level may also have considerable detrimental effects. It may result in a reduction in academic standards and this, in turn, may make degrees less valuable over time. Similarly, it is also possible to claim that a large number of unprepared

\footnotetext{
${ }^{1}$ Data come from different issues of the Times Higher Education Supplement.

${ }^{2}$ A survey of vice-chancellors in 2004 showed that nearly half of all UK universities (i.e. 48 percent) set up remedial classes in English and math because of the perceived deteriorating quality of undergraduates (The Telegraph, $18^{\text {th }}$ July 2004).
} 
students may demoralize faculty (Pitts et al., 1999). Furthermore, remedial courses are very costly for students, HEIs and society at large. Students are often required to pay tuition fees for courses associated with credits that do not count towards graduation. HEIs typically invest a significant proportion of their resources in programs aimed at helping students who have academic deficiencies. Taxpayers may also be reluctant to bear the cost of remediation as they may question the need to pay twice for the same learning opportunity, first in secondary education and then in university education. Finally, and perhaps most importantly, several opponents of remedial courses call their efficacy into question (Jenkins and Boswell, 2002).

A major difficulty in ascertaining the effectiveness of remedial education lies in the endogeneity of remedial programs. Whilst schools/universities assign students to remedial programs primarily on the basis of observables, selection into remedial education may also be driven by unobservables. Given that standard regression techniques are able to account for the effect of the former but not of the latter on student performance, they do not identify the true effect of remediation. Specifically, the remediation estimate may be biased downward as it picks up the negative influence exerted by these unobserved characteristics on student performance.

In this paper, we analyze the effectiveness of a math remedial course adopted by a School of a post-1992 UK university ${ }^{3}$. A regression discontinuity (RD) design is used in order to address the issue of selection on unobservables into remedial education. Specifically, the RD design exploits the discontinuity induced by the rules used for

\footnotetext{
${ }^{3}$ Universities in England can be divided into two broad categories on the basis of their historical background: pre-1992 universities and post-1992 universities. Whilst the former group comprises those institutions with university status prior to 1992, the latter includes mostly former polytechnics that received university status when the Further and Higher Education Act of 1992 came into force.
} 
the assignment to remedial classes. HEIs typically use a diagnostic placement test to assess first-year students' entering skill levels. While students whose test score is below a given cutoff are assigned to remedial courses, those who achieve a score above this cutoff are not referred to remedial classes. The idea of the RD design is to compare the average outcome of students whose result is just above the minimum score requirement with the average outcome of their peers who have scored just below the cutoff. Given that these two groups of students are basically thought to have the same observed (and unobserved) academic ability, the former group represents a good proxy of what would have happened to students if they had not attended remedial courses. The intuition behind the RD design is that it emulates a random experiment at the cutoff point (Lesik, 2008). The probability of attending remedial classes can be interpreted as being random for those students whose score is in the close neighborhood of the cutoff.

Our work adds to previous research on effectiveness of remedial education at university/college level in three main aspects. First, very few studies focus their attention on the UK (one exception is the paper by Lagerlöf and Seltzer (2009), which is discussed in the next Section). Papers on the US (typically based on experiences from Community Colleges) tend to dominate the empirical literature in this area and, whilst these studies are instructive, it would be rather hazardous to make inference exclusively based on them. Second, not only are there few UK-based studies, but these tend to examine pre-1992 universities. However, remediation is likely to be less relevant in these institutions given that their admission standards are generally higher ${ }^{4}$

\footnotetext{
${ }^{4}$ Jerrim (2008) shows that average students' university entry score is substantially higher in pre-1992 universities relative to post-1992 universities.
} 
and the majority of students have traditional entry qualifications (i.e. A-levels) ${ }^{5}$. By contrast, one would expect remediation to play a more important role in post-1992 universities where most students show lower academic ability and have non-standard entry qualifications (e.g. Advanced General National Qualification, Access courses and foundation years) ${ }^{6}$. Coffield and Vignoles (1997) report that the proportion of students with alternative entry qualifications is considerably higher in post-1992 universities, when compared to pre-1992 universities. The latter are reluctant to vary their entry requirements as they fear that this change would result in admitting less able students. Third, to the best of our knowledge, this is the first paper that investigates whether the timing of remediation matters. The effectiveness of remedial education is measured against student performance in a math-based course that is compulsory for both remedial and nonremedial students. While some of the remedial students attend the remedial program prior to this course, for others both run at the same time ${ }^{7}$. In this paper, we analyze whether this difference in timing affects the effectiveness of remedial education ${ }^{8}$.

The remainder or the paper is organized as follows. Section 2 briefly reviews the existing literature on the effectiveness of remedial programs offered at university/college level. Section 3 describes the remediation policy adopted by the School under examination. It comprises information about the math diagnostic test

\footnotetext{
${ }^{5}$ Lagerlöf and Seltzer (2009) look at the experience of a pre-1992 university and their sample includes only students who took A-levels prior to university.

${ }^{6}$ Another distinct feature of post-1992 universities is that they comprise many students from ethnic minority groups (Shiner and Modood, 2002; Tolley and Rundle, 2006). This is due not only to minority students having average lower entry scores and being more likely to have non-traditional entry qualifications than whites, but also to other factors such as lower geographical mobility. Ethnic minority applicants tend to favor institutions in their home region even though they could apply to more distant universities that provide a better match with their academic ability.

${ }^{7}$ Remedial students are randomly allocated to remedial programs taking place either before or at the same time as the math-based course.

${ }^{8}$ Another advantage of our study is the sample size. We use a relatively large sample considering that it only comprises data from one institution. For instance, our sample is much larger than the one employed by Lagerlöf and Seltzer (2009) and hence we expect the estimates to be more precise.
} 
and how students are assigned to remedial education. Section 4 depicts the RD design and how it is implemented in this study. Section 5 presents the data and tests the validity of the RD design in our context. Section 6 reports and discusses the empirical results. Section 7 concludes.

\section{RELATED LITERATURE}

Although there are a large number of studies looking at the effectiveness of university and college remedial courses, only few of them, typically published since 2005, employ a rigorous methodology that properly controls for the endogeneity bias associated with remediation. These studies, however, have produced conflicting results.

On the one hand, some papers show that remediation has a positive impact on educational outcomes. Bettinger and Long (2009) analyze the effects of remediation at four-year colleges in Ohio. To account for the endogeneity bias of remediation, they use an instrumental variable (IV) strategy that relies on both variation in remedial placement policies and the importance of proximity in college choice. Their results suggest that math and English remediation decreases the probability of dropping out of university and increases the likelihood of earning a degree. Furthermore, in line with expectations, remediation is found to be more beneficial to students on the margin of requiring remediation relative to the general sample. A similar result is obtained by Moss and Yeaton (2006) who use an RD design in an attempt to examine the effectiveness of a remedial English course offered by a large, multicampus community college. Not only do they find that remediation significantly improves English academic achievement, but they also conclude that students who are most in need of remedial education receive the most benefits. Additional evidence 
supporting the effectiveness of remedial education is provided by Lesik (2006) who analyses data from a single, four-year metropolitan university located in the Northeast of the US. Employing an RD design and an IV strategy, she shows that participation in a developmental mathematics program increases the likelihood of successfully completing a college-level math course on the first entry.

On the other hand, the effectiveness of remedial education has been questioned by other papers. Using longitudinal administrative data from Texas and employing an RD design, Martorell and McFarlin (2010) find that there is little empirical evidence suggesting that remedial courses have a beneficial impact on student outcomes. Calcagno and Long (2008) analyse data from 28 community colleges in Florida and conclude that, whilst remediation has some benefits in terms of promoting early persistence in college, it does not have a statistically significant impact on degree completion. They employ an RD design that exploits the fact that remedial placement in Florida mainly depends on the score obtained in the Florida College Entry Level Placement Test (CPT). Finally, the scarce evidence from the UK seems also to indicate that the link between remediation and student outcomes is pretty weak. Lagerlöf and Seltzer (2009) analyze the effectiveness of a math remedial course attended by a subset of students in the economics department at a British university. Their study, which relies on a difference-in-differences (DiD) methodology, finds that participation in this remedial course does not have a significant effect on students' performance in economics subjects. By contrast, secondary school grades in mathematics appear to be strong predictors of student academic outcomes. 


\section{BACKGROUND}

In this paper, we assess the effectiveness of remediation by looking at the experience of a large School of a post-1992 UK university where all students enrolling for the first time are required to take an on-line multiple-choice diagnostic test in math ${ }^{9}$. They can take it remotely at anytime between approximately three weeks before the induction starts and the end of this session. Students are told not get any help from anyone in completing the test. This is because their result will determine whether they need additional help with quantitative skills and, if this is the case, they will be enrolled on an appropriate course. Students have 30 minutes to complete the test, can only attempt it once and have no information on the pass mark.

The math screening test is designed to assess basic algebraic skills including simplifying algebraic expressions and fractions, manipulating roots and exponents and factoring and expanding polynomials. The material of this test is aligned with the content of those first-year courses that have a math component. This permits faculty to set up a predetermined cutoff score on the diagnostic test.

While students whose score on the screening math test is below a given cutoff value are automatically enrolled on a remedial math course, those who scored equal or above this cutoff are exempted from it. There are no exceptions to this rule. One should note that, though the math course is remedial in nature, its successful completion confers the same amount of degree-counting credits ${ }^{10}$ as any of the other

\footnotetext{
${ }^{9}$ Students who have not taken this test cannot be formally registered.

${ }^{10}$ This is very important since in the US remedial courses generally do not confer degree-counting credits.
} 
first-year courses ${ }^{11}$. This means that students failing the placement standardized test have one less optional course to choose from during their first year of study relative to their peers who have passed the test. Conferring credits is a crucial feature for remedial courses as it may increase their effectiveness. Several studies (see, for instance, Deil-Amen and Rosenbaum, 2002) show that students who take several remedial courses without earning credit for a degree are more likely to drop out than other students. The former students may develop a low level of self-confidence in their ability which, in turn, may have a negative effect on their educational outcomes.

In this study, the effectiveness of the math remedial course is measured by comparing the performance of remedial and nonremedial students in a math-based course, which all first-year students are required to take. Such a course comprises two pieces of assessment. The first component, which accounts for $30 \%$ of the total course score, consists of a written report submitted by the student at the end of the teaching period. The second component, which is worth $70 \%$ of the total course score, is a final examination that students take at the end of the academic year.

The academic year is divided into two teaching semesters and the math remedial course and the compulsory first-year math-based course are run in both semesters. Students can either take the two courses concurrently (either both in the first semester or both in the second semester) or they can take the former in the first semester and the latter during the second semester. The final timetable is randomly generated by a software package used by the School. The content of these two courses, their assessment regime and their teaching staff and method have all not changed during

\footnotetext{
${ }^{11}$ Students are required to take eight courses during the first year, i.e. four in the first semester and four in the second semester.
} 
the three academic years under examination. This means that student performance in these courses is comparable over this period.

\section{IDENTIFICATION STRATEGY}

In this section we sketch the $\mathrm{RD}$ design employed to estimate the effect of remedial education on student academic outcomes. A sharp RD design (see, for instance, Ou, 2010; Filmer and Schady, 2011) is used given that assignment to remedial education is a deterministic and discontinuous function of the score on the diagnostic math test. While students scoring below a predetermined cutoff are put into a remedial math course, those whose score is equal or higher to the cutoff are exempted from the remedial course. One simple way of estimating the effect of remediation is to compare the average outcome of the group just above the cutoff with the average outcome of the group just below the cutoff. However, this procedure may lead to very imprecise estimates of the remediation effect given that typically barely passers and barely failers make up only a small sample of the student population. Therefore an equivalent but more efficient method is to employ all available data and a control function approach (Petterson-Lidbom, 2008). This involves regressing the outcome of interest (i.e. student performance in the compulsory first-year math-based course) against a polynomial in the assignment variable (i.e. score on the diagnostic math test); that is, the control function, and a dichotomous indicator for remedial and nonremedial status. Hence our estimation equation is:

$y_{i}^{t}=\alpha_{0}+\alpha_{1} R E M_{i}^{t}+f\left(\operatorname{SCORE}_{i}^{t}\right)+\eta^{t}+\varepsilon_{i}^{t}$

where $y_{i}^{t}$ is the performance of student $\mathrm{i}$ in cohort $\mathrm{t}$ in the compulsory first-year math-based course; $R E M_{i}^{t}$ is a dummy variable that takes the value 1 if student $\mathrm{i}$ in cohort $\mathrm{t}$ is assigned to the math remedial course, and zero otherwise; $f\left(S C O R E_{i}^{t}\right)$ is 
an unknown smooth function of the score obtained by student $\mathrm{i}$ in cohort $\mathrm{t}$ in the math diagnostic test; $\eta^{t}$ is a cohort-specific intercept and $\varepsilon_{i}^{t}$ is an error term. The inclusion of $f\left(S C O R E_{i}^{t}\right)$ as a regressor is expected to capture any correlation between $R E M_{i}^{t}$ and $\varepsilon_{i}^{t}$, and therefore $\alpha_{1}$ will be an unbiased estimate of the effect of remediation on student performance in the compulsory first-year math-based course ${ }^{12}$.

Although, in principle it is not necessary to include additional covariates in Equation (1), their introduction can be justified on two grounds. First, it allows for variance reduction and this is important given that the $\mathrm{RD}$ technique has large sampling variability. Second, the inclusion of these additional covariates can also be thought as a check for the plausibility of the identification strategy. An underlying assumption of our RD approach is that, conditional on $f\left(S C O R E_{i}^{t}\right)$, the only source of discontinuity in student performance at the cutoff score should be failing the math screening test. Therefore if this assumption is met, one would expect the presence of control variables not to significantly affect the effect of remediation. Incorporating the covariates, the estimation equation becomes the following:

$y_{i}^{t}=\alpha_{0}+\alpha_{1} R E M_{i}^{t}+f\left(S C O R E_{i}^{t}\right)+\alpha_{2} \operatorname{SEM} 2_{i}^{t}+X_{i}^{t^{\prime}} \psi+\eta^{t}+\varepsilon_{i}^{t}$

where $S E M 2_{i}^{t}$ is a dummy variable that takes the value 1 if student $\mathrm{i}$ in cohort t took the compulsory math-based course in the second semester, and zero otherwise ${ }^{13} ; X_{i}^{t}$

\footnotetext{
${ }^{12}$ As we have no data on attendance of the math remedial course, what we identify is the impact of being enrolled on this course. This means that $\alpha_{1}$ is an "intent-to-treat" parameter. As observed by Bandiera et al. (2010), student enrolment is a more interesting policy parameter for universities relative to student attendance. Whilst the former can be easily measured and manipulated by them, this does not hold for the latter.

${ }^{13}$ The rationale for including the second semester dummy follows. Given that the final examination for the compulsory first-year math-based course takes place at the end of the academic year for students who attended this course in the first semester as well as for those who took it in the second semester, (other things being equal) one would expect the latter group to perform, on average, better than the
} 
is a vector that includes a set of control variables (i.e. age, gender, nationality, ethnicity and socio-economic background ${ }^{14}$ ) for student $\mathrm{i}$ in cohort $\mathrm{t}$.

We consider two different indicators of student performance in the compulsory firstyear math-based course: 1) a binary variable that takes the value 1 if the student has successfully completed the course, and zero otherwise; 2) the overall score (out of 100) received by the student in the course. The rationale for including the first measure is that first-year students may have little incentives for getting high scores on their examinations as scores in first-year subjects do not count towards the final degree classification (this occurs in most UK universities).

Because in the academic year 2009-2010 the cutoff score on the math screening test is one-point lower than that in the academic years 2007-2008 and 2008-2009 ${ }^{15}$, this was redefined by subtracting the cohort-specific cutoff score from each student's score.

\section{DATA AND TESTS OF THE VALIDITY OF THE RD DESIGN}

Our data comprise student-level observations for three consecutive cohorts of firstyear students in the academic years 2007-2008, 2008-2009 and 2009-2010. From this sample, we exclude remedial students who did not take the exam for the remedial math course (i.e. 49 students). In addition, we remove from the sample those students who did not participate in any of the two assessments of the compulsory math-based

former one. The long delay between the end of the course and the examination may in fact have a detrimental effect on student achievement.

${ }^{14}$ We use occupation of parent or guardian as a proxy for socio-economic background.

${ }^{15}$ However, in the academic year 2009-2010 the number of questions included on the math diagnostic test were two less than that included in the academic years 2007-2008 and 2008-2009. 
course (i.e. 145 students). This leaves a sample of 1,521 students ${ }^{16}$. Columns 1, 2 and 3 of Table 1 report the descriptive statistics of our dependent and independent variables for the whole sample, nonremedial students and remedial students, respectively. Approximately 33.3\% of first-year students have failed the diagnostic test and hence have been assigned to the math remedial course. Unfortunately, we do not have information on the socio-economic background of many students. However, in order to maximize the sample size, we keep these observations and create a dummy variable indicating missing status. Column 4 of Table 1 presents the difference in means between remedial and nonremedial students. In line with the findings obtained by similar studies (see, for instance, Attewell et al., 2006), remedial students are more likely to be older, more likely to come from an ethnic minority group and more likely to have a low socio-economic background relative to nonremedial students.

\section{Insert Table 1 about here}

As outlined in Section 1, the RD design assumes that, in the neighborhood of the cutoff on the math diagnostic test, remedial and nonremedial students have similar observed characteristics. To check for this assumption, Table 2 presents means for remedial students whose adjusted score on the math diagnostic test is not more than two points away from the cutoff (Column 1), nonremedial students whose similar score is up to two points above the cutoff (Column 2), and the difference in means between these two groups (Column 3). This bandwidth is chosen as it comprises a roughly comparable number of students on either side of the cutoff. It also includes a sufficient number of students to obtain meaningful results. Our results show support

\footnotetext{
${ }^{16}$ The number of students included in each cohort is 562 (2007-2008), 553 (2008-2009) and 406 (2009-2010).
} 
for the RD assumption. The samples just below and just above the cutoff are found not to be different in terms of observed characteristics.

\section{Insert Table 2 about here}

As outlined in Section 4, another assumption of our RD design is that the only source of discontinuity at the cutoff score is failing the math screening test. To test for this assumption, we run a set of regressions, where each student characteristic (rather than the outcome of interest) is regressed against alternative specifications of the control function $f\left(S C O R E_{i}^{t}\right)$ and our remediation dummy. The results from these regressions, which are depicted in Table 3, show that there are no discontinuities in predetermined characteristics around the cutoff.

\section{Insert Table 3 about here}

Another threat to identification in our RD design stems from the possibility that the adjusted score on the math diagnostic test is manipulated by the School. Such a possibility, however, seems very limited. The School has no incentive to keep the number of remedial students low as no additional resources are invested in remedial programs. As argued in Section 3, remedial students have one less optional course to choose from as successful completion of the math remedial course confers the same amount of degree-counting credits as any of the other first-year courses. Additionally, as the math diagnostic test is a multiple choice test, this makes manipulation even less likely. In spite of these arguments, following the approach of Carrell et al. (2011), in Figure 1 we look at whether there are sharp breaks in the distribution of the adjusted score on the math diagnostic test near the cutoff. In particular, we are interested to see 
whether it has a peak in zero. We test for this by using linear and quadratic functions to approximate the distribution of our assignment variable and find that in both cases the observed number of students at the cutoff is predicted by the overall distribution, without any significant departure.

\section{Insert Figure 1 about here}

Before turning in the next Section to the estimates of Equations (1) and (2), in Figure 2 we depict the relationship between the adjusted score on the math diagnostic test and student performance in the compulsory first-year math-based course, using pooled data from the three cohorts. This Figure shows the raw average student outcome at each value of the adjusted score, as well as predictions from a linear function of $S C O R E_{i}^{t}$. Whilst in panel A of Figure 2 student performance is proxied by the overall score on the math-based course, in panel B a simple binary outcome (pass or fail) is used. Looking at both panels, in line with our expectations, student performance is an increasing function of the adjusted score on the math diagnostic test. However, one may note that in both panels there seems to be no discontinuity in student performance at the cutoff based on the math diagnostic test. Additionally, although graphically it appears that the distribution of the scores is fairly linear, in the next Section we will test whether our RD estimates are robust across specifications that include higher order polynomials of $\operatorname{SCORE}_{i}^{t}$.

\section{Insert Figure 2 about here}

\section{EMPIRICAL RESULTS}

Table 4 presents regression discontinuity estimates of the effect of remediation on student performance in the first-year compulsory math module. Whilst for the binary 
student outcome variable (i.e. pass or fail) we employ the maximum likelihood probit technique to estimate the models, for the continuous student outcome variable (i.e. overall score) OLS models are estimated. Following Lee and Card (2008), standard errors are clustered at the adjusted score (on the math diagnostic test) level as this is appropriate in RD frameworks where the assignment variable is discrete. Additionally, given that a big concern in $\mathrm{RD}$ design is whether the control function is correctly specified, we employ four alternative specifications of $f\left(S C O R E_{i}^{t}\right)$. Columns 1 through 4 depict estimates of the regression discontinuity parameter $\alpha_{1}$ from Equation (1) where we use linear, quadratic, cubic and quartic controls for the adjusted score on the math diagnostic test, respectively. In all these specifications this parameter has a negative sign and it is not statistically significant at the conventional levels. Therefore these estimates not only show that the remediation effect is indistinguishable from zero, but also that such a finding is not sensitive to different specifications of the control function.

\section{Insert Table 4 about here}

We then perform another sensitivity check by adding control variables to our specifications. Columns 5 thorough 8 of Table 4 report estimates of $\alpha_{1}$ from Equation (2) where linear, quadratic, cubic and quartic polynomials of $S C O R E_{i}^{t}$ are included, respectively. The results confirm the appropriateness of the use of the RD framework in this context. They show that our RD estimates are not significantly affected by the inclusion of covariates ${ }^{17}$.

\footnotetext{
${ }^{17}$ The estimates reported in the first row of Table 4 are broadly consistent with those obtained when student performance is measured by the score on the end of course report. These estimates are available upon request from the author.
} 
As an additional sensitivity check, Table 5 presents estimates of the remediation effect when we use a discontinuity sample (i.e. it only includes data that are \pm 2 points from the cutoff). Columns 1 and 2 depict estimates from specifications without and with controls, respectively. In these specifications no controls for the adjusted score on the math diagnostic test are included, under the assumption that among those students sufficiently close to the cutoff, assignment to remedial education is basically random. Again, all the estimated RD coefficients have a negative sign and they are not statistically significant at the usual levels, though the size and the standard errors are larger than those reported in Table 4.

\section{Insert Table 5 about here}

Next we extend our empirical analysis by addressing the issue of the possible heterogeneity of remediation across students. Specifically, we examine whether taking the math remedial course before or at the same time as the compulsory firstyear math-based course has any effect on the effectiveness of remediation. Theoretical arguments can be put forward to support both hypotheses. On the one hand, one may argue that it would be better for students to attend the math remedial course first. This gives them an opportunity to build on what they have learnt in the remedial classes. Additionally, students would have the time for proper digestion of remedial material and maturing of ideas and understanding. On the other hand, however, there are also reasons supporting the hypothesis that taking these courses simultaneously is beneficial. In so doing, for instance, there would be no need for students to spend time in revisiting earlier lessons. Students may also be more ready to learn as they have an immediate opportunity to apply the skills acquired in the remedial course to another course. 
To test whether taking the math remedial course at the same time as the compulsory first-year math-based course affects the effectiveness of remediation, we restrict our sample to those remedial students who have taken these courses in the same semester (either both in the first semester or both in the second semester) plus all nonremedial students. Columns 1 through 4 of Table $6^{18}$ show the regression discontinuity estimates for this subsample. Results are presented for RD specifications that include linear, quadratic, cubic and quartic controls for the adjusted score on the math screening test. All these estimates do not provide support for the proposition that taking the math remedial course simultaneously with the compulsory first-year mathbased course makes remediation effective.

\section{Insert Table 6 about here}

Especially in light of the results discussed above, we now look at the question whether it would be best for students to take the math remedial course prior to the compulsory first-year math-based course. Hence we include in our sample those remedial students who have attended the math remedial course in the first semester and the compulsory first-year math-based course in the second semester plus those nonremedial students who have taken the latter in the second semester (control group). Also in this case, the estimates, which are reported in Columns 5 through 8 of Table 6, provide no evidence that remediation works. For the overall score on the compulsory first-year math-based course, the estimates have a negative sign and they are not statistically significant at the conventional levels across all specifications. For the binary outcome (pass or fail), though the regression discontinuity parameter is weakly statistically significant (i.e. at the $10 \%$ level) in specifications comprising linear and

\footnotetext{
${ }^{18}$ Estimates presented in Table 6 remain largely unchanged once covariates are added to all specifications.
} 
quadratic controls for the adjusted score on the math diagnostic test, it becomes statistically insignificant when higher order polynomials of $f\left(S C O R E_{i}^{t}\right)$ are included.

Finally, we explore the possibility that remediation may affect student performance in different first-year courses than the math-based one. The rationale for this is that, since the remedial program makes it easier for students to understand the material of the math-based course, they may decide to reallocate their time and efforts to other subjects. This 'indirect' effect may be particularly relevant given that, as outlined above, scores on first-year courses do not count towards the final degree classification. While Columns 1 through 4 of Table 7 present estimates of the effect of remediation on student performance in a compulsory first-year economics-based course, Columns 5 through 8 depict similar estimates for a compulsory first-year human resources course $^{19}$. The regression discontinuity parameter is never statistically different from zero, which implies that not only does remediation have no discernible effect on student performance in the math-based course, but also in other first-year compulsory courses.

\section{Insert Table 7 about here}

\section{CONCLUSIONS}

In this paper, we have analyzed the short-term effectiveness of a math remedial course adopted by a School of a post-1992 UK university. Whilst there is a significant body of US-based literature looking at the impact of remedial programs on student achievement at university/college level, much less evidence is available for the UK. This is unfortunate given that in the last decades in the UK the unprecedented

\footnotetext{
${ }^{19}$ Estimates presented in Table 7 remain largely unchanged once covariates are added to all specifications.
} 
expansion of participation in higher education has been accompanied by an increase in the number of students who are perceived to be unprepared to study at this level. They often lack academic skills in crucial areas such as mathematics, reading and writing. Additionally, as these students are more likely to come from an ethnic minority group and from a disadvantaged background, remedial courses may play an important role in improving their educational opportunities.

Using a regression discontinuity approach to account for the endogeneity bias caused by the potential correlation between attending remedial classes and unobserved characteristics negatively affecting student achievement, we have found no empirical evidence suggesting that remediation is effective. Specifically, our findings indicate that attending the math remedial course does not improve student performance in a math-based course. Additionally, our empirical results show that the effectiveness of remediation does not depend on its timing. Taking the math remedial course at the same time or prior to the compulsory math-based course does not change the conclusion mentioned above. Finally, our estimates do not support the proposition that the math remedial program improves student performance in compulsory firstyear courses different from the math-based one.

Not only are our findings in line with those of a recent study by Lagerlöf and Seltzer (2009), which is based on data from another UK higher education institution, but they also complement each other. Remediation does not seem to work neither in a post1992 university nor in a pre-1992 university. While Lagerlöf and Seltzer (2009) find that remediation is ineffective for the group of remedial students as a whole, our study suggests that the same conclusion holds for those remedial students whose score on 
the math diagnostic test is close to the cutoff ${ }^{20}$. Therefore, taken together, the results from these two studies may underscore the need to review remediation policy offered at university level in the UK.

While efforts have to be made to improve university remediation policy in the UK, fewer resources are likely to be available towards this given the current financial climate in the higher education sector. In light of the proposed withdrawal of public subsidies (December 2010), UK universities could potentially face funding cuts up to $40 \%$ over the next four years. While universities are putting forward their plans on areas where expenditure can be reduced, ineffective remedial programs appear to be quite an obvious candidate.

\footnotetext{
${ }^{20}$ In contrast to DiD estimates, RD estimates are not applicable to the entire student population as they only estimates remediation effects around a narrow interval (the local effect is estimated).
} 


\section{REFERENCES}

Attewell, P., Lavin, D., Domina, T. and Levey, T. (2006). 'New evidence on college remediation', Journal of Higher Education, Vol.77, pp. 886-924.

Bandiera, O., Larcinese V. and Rasul, I. (2010). 'Heterogeneous class size effects: new evidence from a panel of university students', Economic Journal Vol. 120, pp. 1365-1398.

Bettinger, E. P. and Terry Long, B. (2009). 'Addressing the needs of underprepared students in higher education: Does college remediation Work?', Journal of Human Resources, Vol. 44, pp. 736-771.

Calcagno, J. C., and Terry Long, B. (2008). 'The impact of postsecondary remediation using a regression discontinuity approach: Addressing endogenous sorting and noncompliance', Working Paper No. 14194, NBER .

Carrell, S. E., Hoekstra, M. and West, J. E. (2011). 'Does drinking impair college performance? Evidence from a regression discontinuity approach’, Journal of Public Economics, Vol. 95, pp. 54-62.

Coffield, F., and Vignoles, A. (1997). 'Widening participation in higher education by ethnic minorities, women and alternative students', Report No 5, The National Committee of Inquiry into Higher Education. Newcastle, Department of Education.

Deil-Amen, R. and Rosenbaum, J. E. (2002). 'The unintended consequences of stigma-free remediation', Sociology of Education, Vol. 75, pp. 249-68.

Filmer, D. and Schady, N. (2011). 'Does more cash in conditional cash transfer programs always lead to larger impacts on school attendance', Journal of Development Economics, Vol. 96, pp. 150-157.

Imbens, G. W. and Lemieux, T. (2008). 'Regression discontinuity designs: A simple guide’, Journal of Econometrics, Vol. 142, pp. 615-635.

Jenkins, D. and Boswell, K. (2002). 'State Policies on Community College Remediation: Findings from a National Survey', Denver: Education Commission of the States, Center for Community College Policy.

Jerrim, J. (2008). 'Wage expectations of UK students: how do they vary and are they realistic?’, S3RI Applications and Policy Working Paper A08/08, Southampton Statistical Sciences Research Institute.

Lee, D S. and Card, D. (2008). 'Regression discontinuity inference with specification error', Journal of Econometrics, Vol. 142, pp. 655-674.

Lagerlöf, J. N. M., and Seltzer, A. J. (2009). 'The effects of remedial mathematics on the learning of economics: evidence from a natural experiment', Journal of Economic Education, Vol. 40, pp. 115-136. 
Lesik, S. A. (2008). 'Evaluating developmental education programs in higher education', Issue 4, ASHE/Lumina Policy Brief.

Lesik, S. A. (2006). 'Applying the regression discontinuity design to infer causality with non-random assignment', Review of Higher Education, Vol. 30, pp. 1-19.

Martorell, P, and McFarlin I. (2010). 'Help or hindrance? The effects of college remediation on academic and labor market outcomes', Working Paper, School Texas Project, Texas Education Research Center at UT.

Moss, Brian G., and Yeaton, W. H. (2006). 'Shaping policies related to developmental education: an evaluation using the regression-discontinuity design', Educational Evaluation and Policy Analysis, Vol. 28, pp. 215-229.

Ou, D. (2010). 'To leave or not to leave? A regression discontinuity analysis of the impact of failing the high school exam', Economics of Education Review Vol. 29, pp. 171-186.

Pettersson-Lidbom, P. (2008). 'Do parties matter for economic outcomes? A regression-discontinuity approach', Journal of the European Economic Association, Vol. 6, pp. 1037-1056.

Pitts, J. M., White, W. G., and Harrison, A. B (1999). 'Student academic underpreparedness: Effects on faculty', Review of Higher Education, Vol. 22, pp. 343-365.

Shiner, M. and Modood, T. (2002). 'Help or hindrance? Higher education and the route to ethnic equality', British Journal of Sociology of Education, Vol. 23, pp. 209232.

Tolley, J. and Rundle, J. (2006). 'A review of black and minority ethnic participation in higher education', Aimhigher, London. 
Table 1: Descriptive statistics

\begin{tabular}{|c|c|c|c|c|}
\hline & $\begin{array}{l}\text { All students } \\
\text { (1) }\end{array}$ & $\begin{array}{l}\text { Nonremedial } \\
\text { students } \\
\text { (2) }\end{array}$ & $\begin{array}{l}\text { Remedial } \\
\text { students } \\
\text { (3) }\end{array}$ & $\begin{array}{c}\text { Remedial } \\
\text { students vs } \\
\text { nonremedial } \\
\text { students } \\
\text { (4) }\end{array}$ \\
\hline & Mean & Mean & Mean & $\begin{array}{c}\text { Difference in } \\
\text { means }\end{array}$ \\
\hline $\begin{array}{l}\text { Overall score on the compulsory first-year } \\
\text { math-based course }\end{array}$ & $\begin{array}{c}53.239 \\
(16.375)\end{array}$ & $\begin{array}{c}56.296 \\
(15.752)\end{array}$ & $\begin{array}{c}47.109 \\
(15.890)\end{array}$ & $\begin{array}{c}-9.187 * * * \\
(0.860)\end{array}$ \\
\hline $\begin{array}{l}\text { Successfully completed compulsory first- } \\
\text { year math-based course }\end{array}$ & $\begin{array}{c}0.853 \\
(0.354)\end{array}$ & $\begin{array}{c}0.900 \\
(0.299)\end{array}$ & $\begin{array}{c}0.759 \\
(0.428)\end{array}$ & $\begin{array}{c}-0.141^{* * *} \\
(0.189)\end{array}$ \\
\hline Adjusted score on the math diagnostic test & $\begin{array}{c}2.380 \\
(4.283)\end{array}$ & $\begin{array}{c}4.862 \\
(2.442)\end{array}$ & $\begin{array}{l}-2.599 \\
(2.453)\end{array}$ & $\begin{array}{c}-7.461 * * * \\
(0.133)\end{array}$ \\
\hline Remediation & $\begin{array}{c}0.333 \\
(0.471)\end{array}$ & - & - & - \\
\hline $\begin{array}{l}\text { Compulsory first-year math-based course } \\
\text { taken in the second semester }\end{array}$ & $\begin{array}{c}0.615 \\
(0.487)\end{array}$ & $\begin{array}{c}0.603 \\
(0.490)\end{array}$ & $\begin{array}{c}0.638 \\
(0.481)\end{array}$ & $\begin{array}{c}0.035 \\
(0.026)\end{array}$ \\
\hline Female & $\begin{array}{c}0.508 \\
(0.500) \\
\end{array}$ & $\begin{array}{c}0.490 \\
(0.500)\end{array}$ & $\begin{array}{c}0.543 \\
(0.499)\end{array}$ & $\begin{array}{l}-0.053 * * \\
(0.027)\end{array}$ \\
\hline Age $<$ or $=19$ & $\begin{array}{c}0.588 \\
(0.492) \\
\end{array}$ & $\begin{array}{c}0.621 \\
(0.485) \\
\end{array}$ & $\begin{array}{c}0.524 \\
(0.500) \\
\end{array}$ & $\begin{array}{c}-0.097 * * * \\
(0.027)\end{array}$ \\
\hline \multicolumn{5}{|l|}{ Ethnicity } \\
\hline White & $\begin{array}{c}0.214 \\
(0.410)\end{array}$ & $\begin{array}{c}0.218 \\
(0.413)\end{array}$ & $\begin{array}{c}0.208 \\
(0.406)\end{array}$ & $\begin{array}{l}-0.010 \\
(0.022)\end{array}$ \\
\hline Black & $\begin{array}{c}0.118 \\
(0.322)\end{array}$ & $\begin{array}{c}0.081 \\
(0.273)\end{array}$ & $\begin{array}{c}0.192 \\
(0.394)\end{array}$ & $\begin{array}{c}0.111^{* * *} \\
(0.017)\end{array}$ \\
\hline Bangladeshi/Indian/Pakistani & $\begin{array}{c}0.217 \\
(0.412)\end{array}$ & $\begin{array}{c}0.198 \\
(0.399)\end{array}$ & $\begin{array}{c}0.255 \\
(0.436)\end{array}$ & $\begin{array}{c}0.057 * * \\
(0.022)\end{array}$ \\
\hline Chinese & $\begin{array}{c}0.021 \\
(0.144) \\
\end{array}$ & $\begin{array}{c}0.027 \\
(0.161) \\
\end{array}$ & $\begin{array}{c}0.010 \\
(0.099) \\
\end{array}$ & $\begin{array}{c}-0.017^{* *} \\
(0.008) \\
\end{array}$ \\
\hline Other Asian & $\begin{array}{c}0.046 \\
(0.210)\end{array}$ & $\begin{array}{c}0.044 \\
(0.206)\end{array}$ & $\begin{array}{c}0.049 \\
(0.217)\end{array}$ & $\begin{array}{c}0.005 \\
(0.011)\end{array}$ \\
\hline Other ethnic group or Unknown & $\begin{array}{c}0.384 \\
(0.487) \\
\end{array}$ & $\begin{array}{c}0.433 \\
(0.496) \\
\end{array}$ & $\begin{array}{c}0.287 \\
(0.453) \\
\end{array}$ & $\begin{array}{c}-0.146^{* * *} \\
(0.026)\end{array}$ \\
\hline \multicolumn{5}{|l|}{ Nationality } \\
\hline UK nationality & $\begin{array}{c}0.456 \\
(0.498)\end{array}$ & $\begin{array}{c}0.412 \\
(0.492)\end{array}$ & $\begin{array}{c}0.545 \\
(0.498)\end{array}$ & $\begin{array}{c}0.133 * * * \\
(0.027)\end{array}$ \\
\hline Other EU nationality & $\begin{array}{c}0.258 \\
(0.438)\end{array}$ & $\begin{array}{c}0.285 \\
(0.452)\end{array}$ & $\begin{array}{c}0.204 \\
(0.403)\end{array}$ & $\begin{array}{c}-0.081^{* * *} \\
(0.024)\end{array}$ \\
\hline Non-EU nationality & $\begin{array}{c}0.286 \\
(0.452) \\
\end{array}$ & $\begin{array}{c}0.303 \\
(0.460) \\
\end{array}$ & $\begin{array}{c}0.251 \\
(0.434) \\
\end{array}$ & $\begin{array}{c}-0.052^{* *} \\
(0.025)\end{array}$ \\
\hline \multicolumn{5}{|l|}{ Socio-economic background } \\
\hline High socio-economic background & $\begin{array}{c}0.170 \\
(0.375)\end{array}$ & $\begin{array}{c}0.175 \\
(0.380)\end{array}$ & $\begin{array}{c}0.158 \\
(0.365)\end{array}$ & $\begin{array}{c}-0.017 \\
(0.020)\end{array}$ \\
\hline Intermediate socio-economic background & $\begin{array}{c}0.105 \\
(0.306) \\
\end{array}$ & $\begin{array}{c}0.103 \\
(0.305) \\
\end{array}$ & $\begin{array}{c}0.107 \\
(0.309) \\
\end{array}$ & $\begin{array}{c}0.003 \\
(0.017) \\
\end{array}$ \\
\hline Low socio-economic background & $\begin{array}{c}0.150 \\
(0.357)\end{array}$ & $\begin{array}{c}0.135 \\
(0.342)\end{array}$ & $\begin{array}{c}0.180 \\
(0.384)\end{array}$ & $\begin{array}{c}0.045^{* *} \\
(0.019)\end{array}$ \\
\hline Unknown socio-economic background & $\begin{array}{c}0.576 \\
(0.494)\end{array}$ & $\begin{array}{c}0.586 \\
(0.493)\end{array}$ & $\begin{array}{c}0.555 \\
(0.497)\end{array}$ & $\begin{array}{c}-0.031 \\
(0.027)\end{array}$ \\
\hline Observations & 1,521 & 1,015 & 506 & - \\
\hline
\end{tabular}

Notes:

1) In Columns 1, 2 and 3 standard deviations are in brackets. In Column 4 standard errors are in brackets.

$2)^{* * *}$ denotes statistically significant at $1 \%$; ** denotes statistically significant at $5 \%$; $*$ denotes statistically significant at $10 \%$. 
Table 2: Descriptive statistics for the discontinuity sample ( \pm 2 points from the cutoff on the math diagnostic test)

\begin{tabular}{|c|c|c|c|}
\hline & $\begin{array}{l}\text { Nonremedial students } \\
\text { (1) }\end{array}$ & $\begin{array}{l}\text { Remedial students } \\
\text { (2) }\end{array}$ & $\begin{array}{l}\text { Remedial students vs } \\
\text { nonremedial students } \\
\text { (3) }\end{array}$ \\
\hline & Mean & Mean & Difference in means \\
\hline Female & $0.500(0.501)$ & $0.550(0.498)$ & $0.050(0.045)$ \\
\hline Age $<$ or $=19$ & $0.602(0.491)$ & $0.609(0.489)$ & $0.007(0.044)$ \\
\hline \multicolumn{4}{|l|}{ Ethnicity } \\
\hline White & $0.236(0.426)$ & $0.218(0.414)$ & $-0.018(0.038)$ \\
\hline Black & $0.106(0.309)$ & $0.163(0.370)$ & $0.057 *(0.031)$ \\
\hline Bangladeshi/Indian/Pakistani & $0.241(0.429)$ & $0.263(0.441)$ & $0.022(0.039)$ \\
\hline Chinese & $0.028(0.165)$ & $0.010(0.102)$ & $-0.017(0.012)$ \\
\hline Other Asian & $0.065(0.247)$ & $0.045(0.208)$ & $-0.020(0.020)$ \\
\hline $\begin{array}{l}\text { Other ethnic group or } \\
\text { Unknown }\end{array}$ & $0.324(0.469)$ & $0.301(0.460)$ & $-0.023(0.042)$ \\
\hline \multicolumn{4}{|l|}{ Nationality } \\
\hline UK nationality & $0.509(0.501)$ & $0.543(0.499)$ & $0.034(0.045)$ \\
\hline Other EU nationality & $0.241(0.429)$ & $0.211(0.409)$ & $-0.030(0.038)$ \\
\hline Non-EU nationality & $0.250(0.434)$ & $0.246(0.431)$ & $-0.004(0.039)$ \\
\hline \multicolumn{4}{|l|}{ Socio-economic background } \\
\hline $\begin{array}{l}\text { High socio-economic } \\
\text { background }\end{array}$ & $0.199(0.400)$ & $0.156(0.363)$ & $-0.043(0.034)$ \\
\hline $\begin{array}{l}\text { Intermediate socio-economic } \\
\text { background }\end{array}$ & $0.097(0.297)$ & $0.125(0.331)$ & $0.028(0.028)$ \\
\hline $\begin{array}{l}\text { Low socio-economic } \\
\text { background }\end{array}$ & $0.181(0.386)$ & $0.176(0.382)$ & $-0.005(0.034)$ \\
\hline $\begin{array}{l}\text { Unknown socio-economic } \\
\text { background }\end{array}$ & $0.523(0.501)$ & $0.543(0.499)$ & $0.020(0.045)$ \\
\hline $\begin{array}{l}\text { Compulsory first-year math- } \\
\text { based course taken in the } \\
\text { second semester }\end{array}$ & $0.699(0.460)$ & $0.649(0.489)$ & $-0.050(0.043)$ \\
\hline Observations & 216 & 289 & - \\
\hline
\end{tabular}

Notes:

1) In Columns 1 and 2 standard deviations are in brackets. In Column 3 standard errors are in brackets. $2)^{* * *}$ denotes statistically significant at $1 \%$; ** denotes statistically significant at $5 \%$; $*$ denotes statistically significant at $10 \%$. 
Figure 1: Distribution of observations of the adjusted score on the math diagnostic test near the cutoff

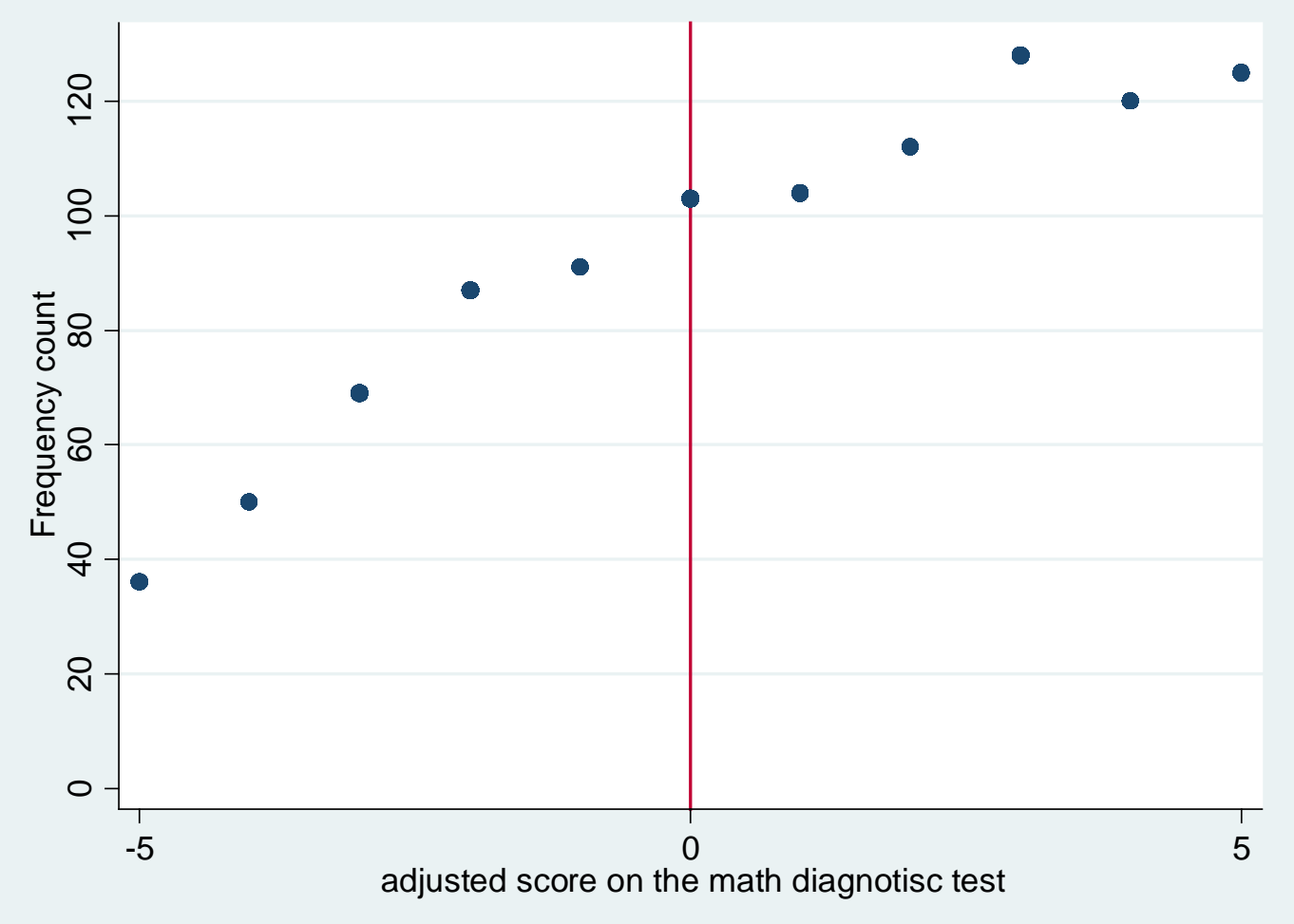


Figure 2: Student performance in the compulsory first-year math-based course and the adjusted score on the math diagnostic test

Panel A: overall score on the compulsory math-based course

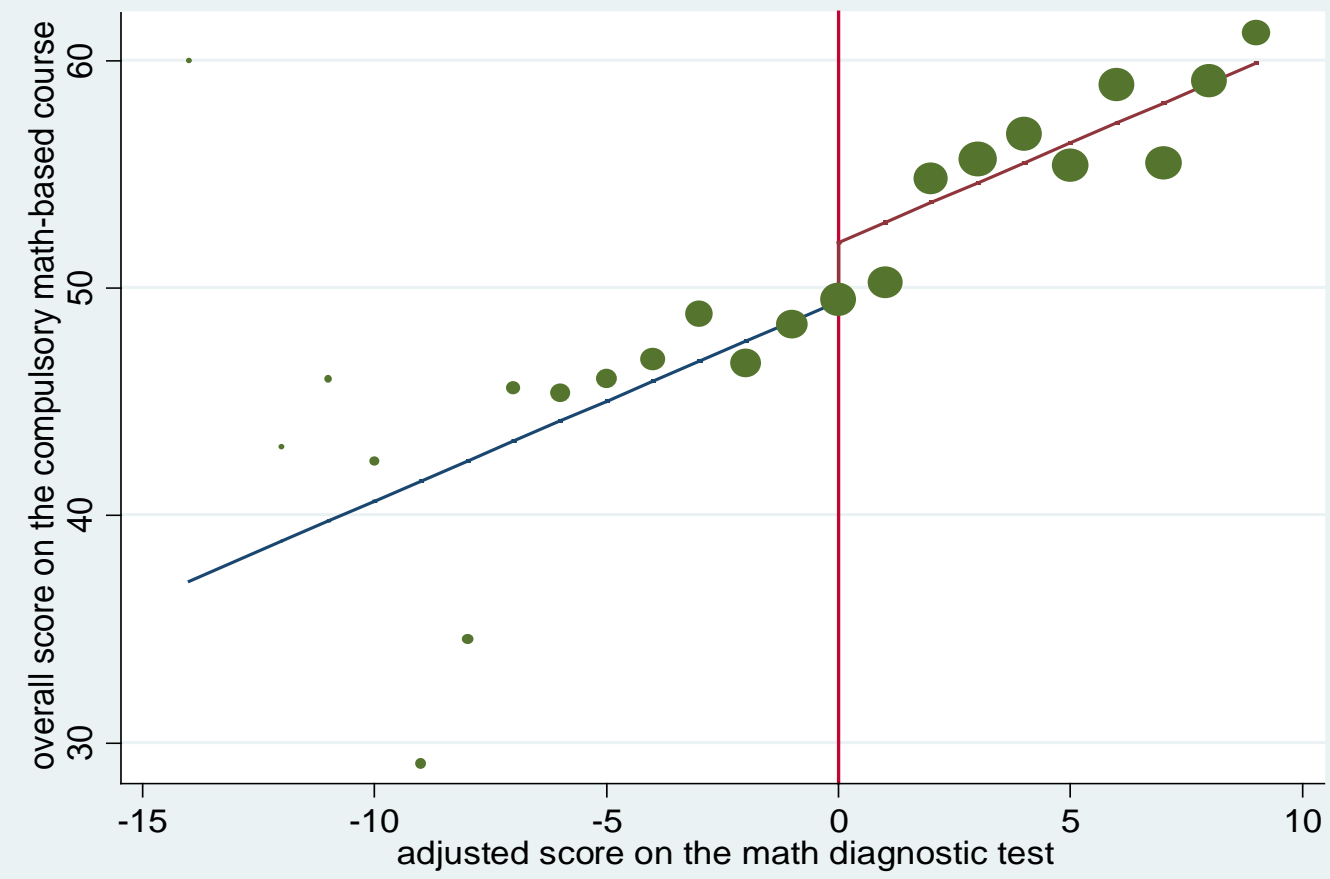

Panel B: probability of passing the compulsory math-based course

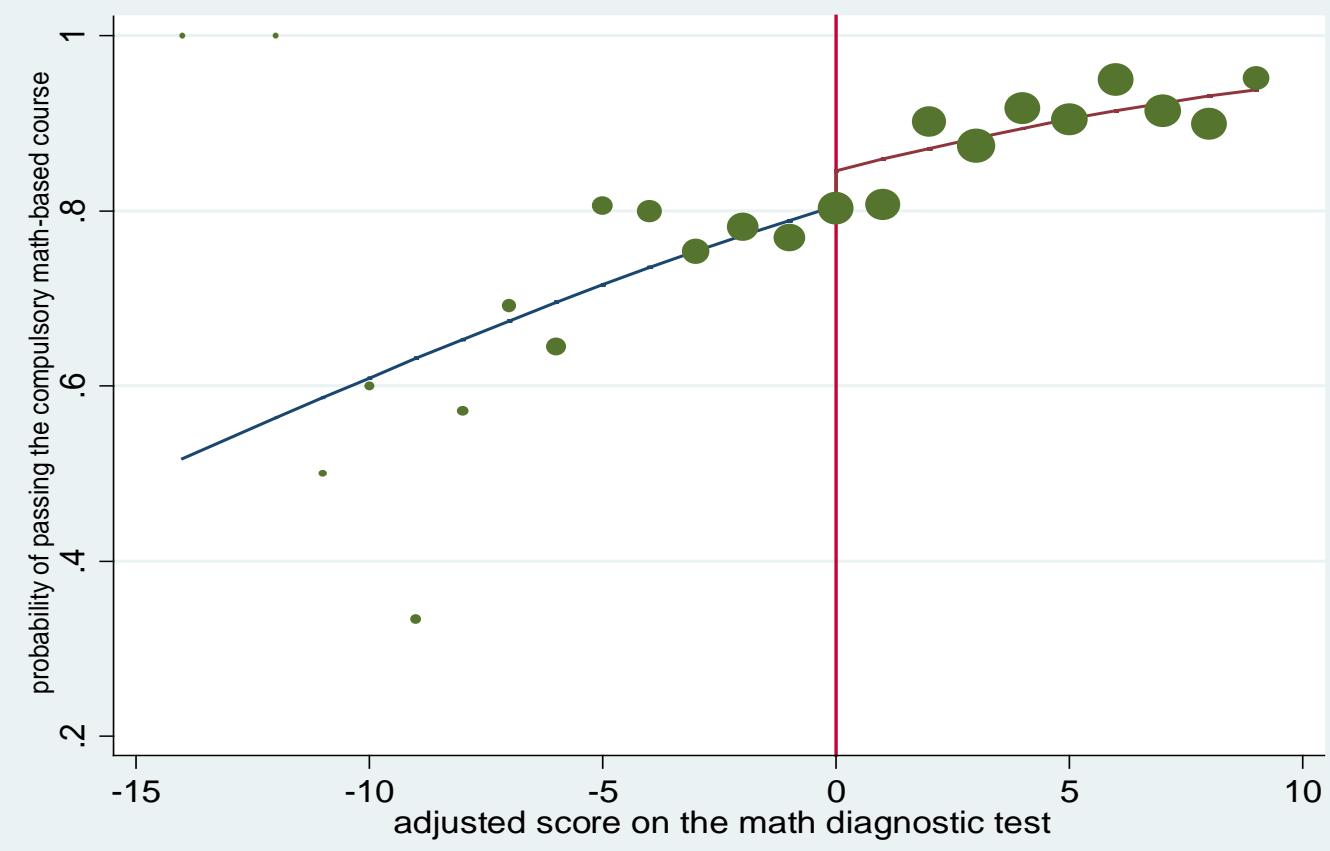

Notes:

1) The figure presents "raw "average student outcome at each value of the adjusted score, along with the fitted values of a linear regression calculated within each of the two segments.

2) In both panels the size of the symbols reflects the number of students in each value of the adjusted score. 
Table 3: Regression discontinuity estimates on pre-determined student characteristics

\begin{tabular}{|c|c|c|c|c|}
\hline $\begin{array}{l}\text { Adjusted score on the math } \\
\text { screening test specification }\end{array}$ & Linear & Quadratic & Cubic & Fourth-order \\
\hline Female & $\begin{array}{c}0.150 \\
(0.120)\end{array}$ & $\begin{array}{c}0.143 \\
(0.121)\end{array}$ & $\begin{array}{c}0.134 \\
(0.151)\end{array}$ & $\begin{array}{c}0.156 \\
(0.155)\end{array}$ \\
\hline Age $<$ or $=19$ & $\begin{array}{c}0.071 \\
(0.121)\end{array}$ & $\begin{array}{c}0.138 \\
(0.123)\end{array}$ & $\begin{array}{c}0.162 \\
(0.153)\end{array}$ & $\begin{array}{c}0.053 \\
(0.157)\end{array}$ \\
\hline White & $\begin{array}{l}-0.093 \\
(0.134)\end{array}$ & $\begin{array}{l}-0.038 \\
(0.137)\end{array}$ & $\begin{array}{l}-0.117 \\
(0.172)\end{array}$ & $\begin{array}{l}-0.119 \\
(0.175)\end{array}$ \\
\hline Black & $\begin{array}{c}0.037 \\
(0.154)\end{array}$ & $\begin{array}{c}0.032 \\
(0.154)\end{array}$ & $\begin{array}{c}0.154 \\
(0.186) \\
\end{array}$ & $\begin{array}{c}0.327 \\
(0.206)\end{array}$ \\
\hline Bangladeshi/Indian/Pakistani & $\begin{array}{c}0.053 \\
(0.132)\end{array}$ & $\begin{array}{c}0.075 \\
(0.133)\end{array}$ & $\begin{array}{c}0.169 \\
(0.165)\end{array}$ & $\begin{array}{c}0.111 \\
(0.169)\end{array}$ \\
\hline Chinese & $\begin{array}{l}-0.375 \\
(0.290)\end{array}$ & $\begin{array}{l}-0.172 \\
(0.339)\end{array}$ & $\begin{array}{l}-0.239 \\
(0.372)\end{array}$ & $\begin{array}{l}-0.520 \\
(0.477)\end{array}$ \\
\hline Other Asian & $\begin{array}{l}-0.265 \\
(0.203)\end{array}$ & $\begin{array}{l}-0.267 \\
(0.204)\end{array}$ & $\begin{array}{l}-0.171 \\
(0.252)\end{array}$ & $\begin{array}{l}-0.173 \\
(0.262)\end{array}$ \\
\hline Other ethnic group or Unknown & $\begin{array}{c}0.099 \\
(0.124)\end{array}$ & $\begin{array}{c}0.045 \\
(0.126)\end{array}$ & $\begin{array}{l}-0.096 \\
(0.160)\end{array}$ & $\begin{array}{l}-0.090 \\
(0.161)\end{array}$ \\
\hline UK nationality & $\begin{array}{l}-0.032 \\
(0.120)\end{array}$ & $\begin{array}{c}0.024 \\
(0.121)\end{array}$ & $\begin{array}{c}0.211 \\
(0.153)\end{array}$ & $\begin{array}{c}0.179 \\
(0.156)\end{array}$ \\
\hline Other EU nationality & $\begin{array}{l}-0.087 \\
(0.131) \\
\end{array}$ & $\begin{array}{l}-0.103 \\
(0.134) \\
\end{array}$ & $\begin{array}{l}-0.176 \\
(0.170) \\
\end{array}$ & $\begin{array}{c}0.167 \\
(0.172) \\
\end{array}$ \\
\hline Non-EU nationality & $\begin{array}{c}0.103 \\
(0.129)\end{array}$ & $\begin{array}{c}0.042 \\
(0.131)\end{array}$ & $\begin{array}{l}-0.094 \\
(0.166)\end{array}$ & $\begin{array}{l}-0.066 \\
(0.169)\end{array}$ \\
\hline $\begin{array}{l}\text { High socio-economic } \\
\text { background }\end{array}$ & $\begin{array}{l}-0.242 \\
(0.142)\end{array}$ & $\begin{array}{l}-0.220 \\
(0.143)\end{array}$ & $\begin{array}{l}-0.165 \\
(0.179)\end{array}$ & $\begin{array}{l}-0.157 \\
(0.183)\end{array}$ \\
\hline $\begin{array}{l}\text { Intermediate socio-economic } \\
\text { background }\end{array}$ & $\begin{array}{c}0.058 \\
(0.161)\end{array}$ & $\begin{array}{c}0.140 \\
(0.165)\end{array}$ & $\begin{array}{c}0.180 \\
(0.206)\end{array}$ & $\begin{array}{c}0.184 \\
(0.209)\end{array}$ \\
\hline $\begin{array}{l}\text { Low socio-economic } \\
\text { background }\end{array}$ & $\begin{array}{l}-0.017 \\
(0.143)\end{array}$ & $\begin{array}{l}-0.008 \\
(0.143)\end{array}$ & $\begin{array}{c}0.027 \\
(0.178)\end{array}$ & $\begin{array}{c}0.020 \\
(0.183)\end{array}$ \\
\hline $\begin{array}{l}\text { Unknown socio-economic } \\
\text { background }\end{array}$ & $\begin{array}{c}0.138 \\
(0.120)\end{array}$ & $\begin{array}{c}0.094 \\
(0.121)\end{array}$ & $\begin{array}{l}0.0009 \\
(0.152)\end{array}$ & $\begin{array}{l}-0.021 \\
(0.155)\end{array}$ \\
\hline
\end{tabular}

Notes:

1) Each entry is a separate regression.

2) Each cell reports estimates on the coefficient of the remediation dummy in a probit regression of a given student characteristic on the control function $f\left(S C O R E_{i}^{t}\right)$. 
Table 4: Regression discontinuity estimates of the effect of remediation on student performance in the compulsory first-year math-based course

\begin{tabular}{|l|c|c|c|c|c|c|c|c|}
\hline & $(1)$ & $(2)$ & $(3)$ & $(4)$ & $(5)$ & $(6)$ & $(7)$ & $(8)$ \\
\hline $\begin{array}{l}\text { Overall score } \\
\text { (OLS) }\end{array}$ & -0.830 & -1.058 & -0.505 & -0.759 & -0.950 & -1.202 & -0.620 & -0.815 \\
\hline $\begin{array}{l}\text { Pass or fail } \\
\text { (Probit) }\end{array}$ & -0.032 & -0.032 & -0.013 & -0.011 & -0.032 & -0.031 & -0.013 & -0.009 \\
$(0.032)$ & $(0.032)$ & $(0.039)$ & $(0.043)$ & $(0.030)$ & $(0.029)$ & $(0.034)$ & $(0.037)$ \\
\hline $\begin{array}{l}\text { Adjusted } \\
\begin{array}{l}\text { score on the } \\
\text { math } \\
\text { screening test } \\
\text { specification }\end{array}\end{array}$ & Linear & Quadratic & Cubic & Quartic & Linear & Quadratic & Cubic & Quartic \\
\hline $\begin{array}{l}\text { Controls } \\
\text { Obs }\end{array}$ & $\mathrm{N}$ & $\mathrm{N}$ & & & & & & \\
\hline
\end{tabular}

\section{Notes:}

1) Each entry is a separate regression.

2) Standard errors are reported in brackets and are clustered at the adjusted score (on the math diagnostic test) level.

3) All regressions include cohort specific effects.

4) OLS coefficients and probit marginal effects are reported.

5) The controls include gender, age, nationality, ethnicity, socio-economic background and the semester dummy. 
Table 5: Regression discontinuity estimates of the effect of remediation on student performance in the compulsory first-year math-based course (discontinuity sample)

\begin{tabular}{|l|c|c|}
\hline & $(1)$ & $(2)$ \\
\hline Overall & -3.733 & -3.599 \\
score & $(2.302)$ & $(1.976)$ \\
(OLS) & & \\
\hline Pass or fail & -0.065 & -0.064 \\
(Probit) & $(0.044)$ & $(0.039)$ \\
\hline Controls & $\mathrm{N}$ & $\mathrm{Y}$ \\
\hline Obs & 505 & 505 \\
\hline
\end{tabular}

Notes:

1) Each entry is a separate regression.

2) Standard errors are reported in brackets and are clustered at the adjusted score (on the math diagnostic test) level.

3) All regressions include cohort specific effects.

4) OLS coefficients and probit marginal effects are reported.

5) The controls include gender, age, nationality, ethnicity, socio-economic background and the semester dummy. 
Table 6: Regression discontinuity estimates of the effect of the timing of remediation on student performance in the compulsory first-year math-based course

\begin{tabular}{|c|c|c|c|c|c|c|c|c|}
\hline \multirow[t]{2}{*}{$\begin{array}{l}\text { Timing of } \\
\text { remediation }\end{array}$} & \multicolumn{4}{|c|}{$\begin{array}{l}\text { Math remedial course taken at the same time } \\
\text { as the compulsory first-year math-based } \\
\text { course }\end{array}$} & \multicolumn{4}{|c|}{$\begin{array}{l}\text { Math remedial course taken prior to the } \\
\text { compulsory first-year math-based course }\end{array}$} \\
\hline & (1) & (2) & (3) & (4) & (5) & (6) & (7) & (8) \\
\hline $\begin{array}{l}\text { Overall score } \\
\text { (OLS) }\end{array}$ & $\begin{array}{c}0.848 \\
(1.871)\end{array}$ & $\begin{array}{c}0.087 \\
(1.929)\end{array}$ & $\begin{array}{c}1.943 \\
(2.192)\end{array}$ & $\begin{array}{c}1.913 \\
(2.317)\end{array}$ & $\begin{array}{l}-2.067 \\
(2.169)\end{array}$ & $\begin{array}{l}-2.394 \\
(2.077)\end{array}$ & $\begin{array}{l}-3.440 \\
(2.731)\end{array}$ & $\begin{array}{l}-3.446 \\
(2.477)\end{array}$ \\
\hline $\begin{array}{l}\text { Pass or fail } \\
\text { (Probit) }\end{array}$ & $\begin{array}{l}-0.014 \\
(0.047)\end{array}$ & $\begin{array}{l}-0.017 \\
(0.047)\end{array}$ & $\begin{array}{c}0.023 \\
(0.045)\end{array}$ & $\begin{array}{c}0.023 \\
(0.044)\end{array}$ & $\begin{array}{l}-0.065^{*} \\
(0.039)\end{array}$ & $\begin{array}{l}-0.065^{*} \\
(0.042)\end{array}$ & $\begin{array}{l}-0.075 \\
(0.057)\end{array}$ & $\begin{array}{l}-0.066 \\
(0.050)\end{array}$ \\
\hline $\begin{array}{l}\text { Adjusted score } \\
\text { on the math } \\
\text { screening test } \\
\text { specification }\end{array}$ & Linear & Quadratic & Cubic & Quartic & Linear & Quadratic & Cubic & Quartic \\
\hline Obs & 1,268 & 1,268 & 1,268 & 1,268 & 864 & 864 & 864 & 864 \\
\hline
\end{tabular}

Notes:

1) Each entry is a separate regression.

2) Standard errors are reported in brackets and are clustered at the adjusted score (on the math diagnostic test) level.

3) All regressions include cohort specific effects.

4) OLS coefficients and probit marginal effects are reported

$5)^{* * *}$ denotes statistically significant at $1 \%$; ** denotes statistically significant at 5\%; * denotes statistically significant at $10 \%$. 
Table 7: Regression discontinuity estimates of the effect of remediation on student performance in other compulsory first-year courses

\begin{tabular}{|c|c|c|c|c|c|c|c|c|}
\hline & \multicolumn{4}{|c|}{ Economics-based course } & \multicolumn{4}{|c|}{ Human resources course } \\
\hline & (1) & (2) & (3) & (4) & (5) & (6) & $(7)$ & (8) \\
\hline $\begin{array}{l}\text { Overall score } \\
\text { (OLS) }\end{array}$ & $\begin{array}{l}-0.005 \\
(0.947)\end{array}$ & $\begin{array}{l}-0.034 \\
(1.001)\end{array}$ & $\begin{array}{l}-0.753 \\
(0.918)\end{array}$ & $\begin{array}{l}-1.151 \\
(0.838)\end{array}$ & $\begin{array}{c}0.230 \\
(0.965)\end{array}$ & $\begin{array}{c}0.280 \\
(0.965)\end{array}$ & $\begin{array}{c}0.542 \\
(1.055)\end{array}$ & $\begin{array}{c}0.191 \\
(0.896)\end{array}$ \\
\hline $\begin{array}{l}\text { Pass or fail } \\
\text { (Probit) }\end{array}$ & $\begin{array}{c}0.006 \\
(0.016)\end{array}$ & $\begin{array}{c}0.006 \\
(0.016)\end{array}$ & $\begin{array}{c}0.005 \\
(0.020)\end{array}$ & $\begin{array}{c}0.001 \\
(0.021)\end{array}$ & $\begin{array}{l}-0.005 \\
(0.020)\end{array}$ & $\begin{array}{l}-0.005 \\
(0.020)\end{array}$ & $\begin{array}{c}0.009 \\
(0.022)\end{array}$ & $\begin{array}{c}0.001 \\
(0.022)\end{array}$ \\
\hline $\begin{array}{l}\text { Adjusted } \\
\text { score on the } \\
\text { math } \\
\text { screening test } \\
\text { specification }\end{array}$ & Linear & Quadratic & Cubic & Quartic & Linear & Quadratic & Cubic & Quartic \\
\hline Obs & 1,401 & 1,401 & 1,401 & 1,401 & 1,450 & 1,450 & 1,450 & 1,450 \\
\hline
\end{tabular}

Notes:

1) Each entry is a separate regression.

2) Standard errors are reported in brackets and are clustered at the adjusted score (on the math diagnostic test) level.

3) All regressions include cohort specific effects.

4) OLS coefficients and probit marginal effects are reported. 